\title{
Reformáció 500
}

\section{SZABADi IstvÁN*}

\section{A SZILÁGYSÁG HOVATARTOZÁSA A KORA ÚJKORI REFORMÁTUS EGYHÁZKORMÁNYZAT TÜKRÉBEN}

\author{
Kulcsszavak: református egyházkormányzat, Erdély, Tiszántúl, Szilágyság, kettős kapcsolat
}

A tágabb értelemben vett Szilágyság, azaz Kraszna és Közép-Szolnok református egyházmegyéinek Erdéllyel való kapcsolatához szeretnék néhány adalékkal szolgálni. A két nemesi vármegye közjogilag Magyarországhoz tartozott, de a középkor óta kötődött Erdélyhez is. Ez a kötődés közismerten az erdélyi vajdák szolnoki ispánságában (azaz a vármegyében érvényesülő, igazából tisztázatlan „vegyes joghatóságában”, a nádor és a vajda közös irányításában), illetve az erdélyi püspöki egyházmegyéhez való tartozásában fogható meg. Egyéb tekintetben is gyakran vizsgált a terület hovatartozása, Jakó Zsigmond és ôt követve Kristó Gyula új Erdély-fogalmat dolgozott ki, Krasznát és Közép-Szolnokot a történeti Erdélyhez sorolva. Ezt az állitást gondolta újra Hegyi Géza, s a területet - földrajzilag kétségkívül az Alföldhöz való kapcsolódásán túl - társadalmi kapcsolatrendszere alapján is Magyarországhoz kötötte. ${ }^{1}$

Ami az egyházigazgatást illeti, noha a két említett vármegye valóban az erdélyi püspök alá tartozott, de az joghatóságát nem érvényesítette közvetlenül, hanem a Szilágyságot egyes szatmári és ugocsai területekkel együtt a tasnádi püspöki helynök, a vikárius igazgatta, önállóan gyakorolva számos püspöki jogkört is (bíráskodás, vizitáció, ordináció). Valamiféle függetlenséget jelentett ez is a püspöki hatalomtól, amelynek a jelentősége éppen a reformáció térhódításakor derült ki, amikor az említett jogkörökkel a protestáns esperes kezdett élni.

Az erdélyi püspökség Meszesen túli részének önállósodása a lutheri tanok térhódításának idejére esett. Ha az 1545, azaz az első tasnádi zsinat után újonnan létrejövő Szatmár-vidéki superintendentia nem is köthető Hevesi Mihályhoz, ahogy azt a hagyomány sokáig ôrizte, ${ }^{2}$ az biztos, hogy az 1557-es kolozsvári hitvitán Hebler Mátyás és Dávid Ferenc mellett Károlyi Boldi Sebestyén már az Erdélytől minden tekintetben független, lutheránus irányú Szatmárvidéki superintendentiát képviselte. ${ }^{3}$ Ennek a superintendentiának, mely a későbbi tiszántúli

* Szabadi István (1964), PhD, Dr. habil., történész, egyetemi docens, Debreceni Egyetem BTK Történelmi Intézet. E-mail: iszabadi@gmail.com.

1 Hegri Géza: Magyarország vagy Erdély? A Szilágyság hovatartozása a középkorban a társadalmi kapcsolatok tükrében. Erdélyi Múzeum LXXIV(2012).3. sz. 23-45.

2 Zoványi Jenő: Hevesi Mihály. Protestáns Szemle XLIV(1935). 1. sz. 22-24.

3 Рокоцч József: Az erdélyi református egyház területi beosztásáról. Protestáns Szemle XI(1899). 5. sz. 319-320. 
egyházkerület egyik magját fogja alkotni, természetesen része az egykori krasznai fóesperesség teljes egészében, illetve az egykori szolnoki főesperesség Szamostól nyugatra eső része. Az új, továbbra is krasznainak, később szilágyinak nevezett protestáns egyházmegye, avagy tractus területe pedig magában foglalta nem csupán Kraszna vármegye területét, hanem Közép-Szolnoknak a Szamos és a Kraszna folyók közé eső részét, azaz lényegében a Tövishátat.

Az új egyházmegye létrejötte további lényeges tanulsággal szolgál. A középkori főesperesség területe követte a világi közigazgatási beosztást, azaz a krasznai főesperesség Kraszna megye területével, a szolnoki pedig Közép-Szolnok és Belső-Szolnok megyék területével esett egybe. A reformációt követően viszont a krasznai, avagy szilágyi tractusba nem tartoztak bele sem az Érmellék, sem Belső-Szolnok egyházközségei. Tehát a középkori keretekből megmaradt az egyházközségi beosztás és mutatis mutandis az esperesség, de utóbbi messze eltért a régi főesperességek és a régi (püspöki) egyházmegye beosztásától. Mindez arra is utal, hogy a reformációt nem felülről kezdeményezték, és vitték véghez, hanem abban meghatározó volt az alsópapságon belüli erjedés. Ami a korai reformációt illeti, mások mellett (Csepregi Zoltán, Dienes Dénes) én is úgy vélem, hogy a papi reformáció nagy jelentőséggel bírt a vidékünkön, s nem kizárólag a patronátus szerepének, főleg nem a gyülekezeteknek, hanem az egyházmegyék fraternitásának volt jelentôs szerepe a folyamatban. A protestáns egyházszervezet kialakulása egyházalkotmányi értelemben akkor indult meg, amikor a protestáns ordináció végzésére önálló tisztséget létesítettek, illetve a már létező lelkészi fraternitások már létező vezetői közül ezzel a feladattal valakit megbíztak. Az alsópapság a régi középkori fraternitásokat fenntartotta, s ezeken dőlt el, hogy egy-egy főesperesség papsága az új tanítások hívévé válik-e. A külföldi akadémiákra el nem jutó leendő lelkészek e fraternitások előtt tettek vizsgát, s itt is ordinálták őket. Erre az első példát a bihari fraternitásban az 1544. évi váradi zsinaton találjuk. Dévai Bíró Mátyás akkori kezdeményezése más vidékeken is követésre talált. ${ }^{4}$ Ezek a fraternitások jellemzően a Partiumban egészen a 18. század végéig megtartották súlyukat és jelentőségüket, leginkább az egyházi központoktól távolabb eső egyházmegyékben (pl. Máramaros, a Debrecenből nézve mindig renitens Bereg, a 18. század folyamán végig elszakadni akaró Kraszna/Szilágy). Az egyháztörténeti hagyomány szerint a Tiszántúli Református Egyházkerület 1557-ben jött létre Kálmáncsehi Sánta Márton tevékenységének köszönhetően, a váradi és a szatmári „superintendentiák” egyesülésével. A korábbi Szatmár-vidéki superintendens, Károlyi Boldi Sebestyén megmaradt lutheránusnak, Erdődön és Krasznabélteken (1557-ig) lelkész és (1554-től) a nagybányai egyházmegye esperese volt. 1555-1557 között a Szatmár-vidéki egyházkerület püspöke volt, ${ }^{5}$ a Tiszántúlt a megerősödött helvét irány miatt, illetve a helvét irányú egyházkerület létrejötte miatt hagyta ott, s ment Kolozsvárra, majd Szászvárosba. Így lehetett az említett 1557-es kolozsvári hitvitán Kálmáncsehi ellenfele. Érdekességként jegyzem meg, hogy a szilágysági reformátusok az 1580-as években még mindig ágostai hitvallásúakként szerepelnek forrásainkban, például Báthory Kristóf 1580. április 24-én, Gyulafehérvárott kelt oklevelében, ${ }^{6}$ mikor a vajda a szilágy-

4 Csepregi Zoltán: A váradi vita 1544-ben = Szentírás, hagyomány, reformáció. Teológia- és egyháztörténeti tanulmányok. Szerk. F. Romнányi Beatrix-KendefFy Gábor. Gondolat, Bp., 2009. 168.

5 Uő: Evangélikus lelkészek Magyarországon (ELEM). Proszopográfiai rész. I. A reformáció kezdetétól a zsolnai zsinatig (1610). I/1: A-L. MEDiT, Bp., 2014. 799.

6 Erdélyi Református Egyházkerület Levéltára (a továbbiakban EREL), B 10 - A Szilágyi traktus levelei, Iratok 1580-1791, 1. tétel. 
sági (in districtu Szilágy) seniornak, másként superintendensnek (!) szabadságot adott a vizitálásra, templomok építésére és javítására, stb. ${ }^{7}$

A Partiumnak Erdélyhez fưződő, jóllehet folyton változó közjogi helyzete valóban meghatározó volt a kerület kialakulása szempontjából. Ahogy a partiumi területek is az erdélyi fejedelmek alá kerültek, az itteni protestáns püspöki hatalom is kizárólagos joggal átvette a potestas ordinist, azaz az ordináció jogkörét. Ezzel jogkörük teljessé vált, és lényegében a középkori püspökök helyébe léptek. Az erdélyi fejedelmi hatalom védelmet adott a Partium reformátusságának is, ennek jelentősége az egyes felekezetek közötti számarányban még ma is tükröződik. Ennek is köszönhető, hogy a szilágysági magyarok mintegy kilencven százaléka ma is a református felekezethez tartozik. Ugyanakkor máig érezhető annak a hatása is, hogy - a megjelent diáknévsorok szerint ${ }^{8}$ - a kora újkori szilágysági lelkészek túlnyomó része nem Nagyenyeden, hanem minden bizonnyal Váradon, 1660 után pedig bizonyítottan Debrecenben kapott képzést, itt szentelték őket lelkésszé, mely szentelés nyilvános disputát, azaz vizsgát követően, tiszántúli zsinatokon történt. Képzettségük, lelkiségük és gondolkodásuk tehát ide, a puritanizmus két kora újkori fellegvárához kötötte őket. A szószéken elhangzott tanítások is ezt a neveltetést tükrözték, s ha attól eltértek, a tiszántúli egyházkerület feladata volt a tanítás megjobbítása, illetve a fegyelmi ügyek lefolytatása. A szilágysági, túlnyomórészt református magyarság sokat emlegetett puritán kegyessége talán ennek a kötődésnek is köszönhető. Debrecenhez kötötte a Szilágyságot a Debreceni Református Kollégium partikularendszere is: az anyaiskolától kapták rektoraikat, akik ugyanazon tankönyvekkel és tanítási módszerrel éltek, mint az anyaiskolában.

A szilágysági református magyarság emlegetett puritánságának tovább élése, egyházhoz való hagyományos ragaszkodása még sokáig megfogható és adatolható. Ilyen például az eklézsiakövetés, amelyet II. József tiltott be, és számos vidéken már az emléke sem maradt fenn, de a Szilágyságban az egyházi fegyelmezés e formája - ti. a szószék alatti szégyenpad használata elsősorban a paráznák és káromkodók kárára - a 20. század elejéig élt. ${ }^{9}$ A 19 . század első feléig gyakorlatban volt az ilyen bünökért járó nyilvános korbácsolás és pálcázás szokása is. ${ }^{10}$

A legújabb korig ugyanazok alkották a helybeli közösséget és a helybeli református egyházközséget, a templom és iskola fenntartására, képzett prédikátor és tanító alkalmazására közös határozattal a községi földekből adtak át egyes birtokrészeket az egyházközség használatába, akár végleges tulajdonába. Kötelező közmunka volt az „Eklézsiai közönséges munka”, azaz a szántás, kapálás, kaszálás, aratás és részvétel az egyházi épületek megépítésében. Azo-

7 Рокоцч József: Az erdélyi református egyház története. IV. Erdélyi Ev. Ref. Egyházkerület Állandó Igazgatótanácsa, Bp., 1904. 46. „A két Báthory: István és Kristóf, az ágostai hitvallást tekintette ezen egyház hivatalos confessiojának, minthogy az 1571 szept. 9-iki medgyesi zsinaton, a mikor Alesius a magyar egyházak püspökévé másodszor is megrálasztatott, a református lelkészek is aláirták az ágostai bitvallást és ennek apologiáját; fentartva az úrvacsora kérdésében eddig elfoglalt kálvini álláspontjukat. Valószinü, hogy Báthory István felfogására tekintettel, késöbb az összes református lelkészek is elfogadták ugyan ilyen módon az ágostai hitvallást és éppen ezért nevezte Báthory Kristóf még 1580-ban is ágostai bitvallásuaknak öket."

8 Juhász István-Jakó Zsigmond: Nagyenyedi diákok 1662-1848. Kriterion, Bukarest, 1979; Intézménytörténeti források a Debreceni Református Kollégium Levéltárában. I-II. Szerk. SzAbadi István. Tiszántúli Református Egyházkerület Levéltára, Debrecen, 2013.

9 Gábriel András: A Szilágyság. Honismeret XX(1992). 5. sz. 46.

10 Petri Mór: Szilágy vármegye monográphiája. I. Szilágy vármegye közönsége, Bp., 1901. 532. 
kat, akik nem jelentek meg, megbírságolták. Az elzárt, nagybirtokos nélküli tövisháti falvakban az egyes családok, nemzetségek úgy ragaszkodtak például a templomi ülésrendhez, mint valami ősi, eredeti szabadságjoghoz. A templomban, mint a közösség ünnepélyes összejöveteleinek helyszínén, az ülésnek szokásos „rendjébez” az előbb ülő „régi”, „eredeti” családok féltékenyen ragaszkodtak a legutóbbi időkig. A templomi „székperek” nyomait számos település irattára megőrizte. Az egyházi élet mindennapjait tehát nem csak az egyház, hanem a világi, a politikai község is felügyelte. ${ }^{11} \mathrm{~A}$ hagyományos, egyházias világképtől aligha független, hogy a szilágysági családokban mindig sok gyermeket vállaltak (ez csak napjainkban kezd megváltozni), ugyanakkor meg kell említeni azt is, hogy a lelkésztársadalom túlnyomó része vagy háromszéki, vagy szilágysági származású, ahogy ez a lelkészi névtárakból is kiderül.

Visszatérve a Szilágyság és Erdély kapcsolatához, abban fordulópontot hozott az 1693-as esztendő, amikor a Partiumot hivatalosan visszacsatolták Magyarországhoz, Kraszna, KözépSzolnok és Zaránd vármegyéket viszont csak az adózás tekintetében, de közigazgatásilag továbbra is Erdélyhez tartoztak. Ez a kettős függés 1732. december 31-ig tartott. Ezután, III. Károly rendelete alapján, Kraszna és Közép-Szolnok minden szempontból a Gubernium fennhatósága alá került, de egyházigazgatásilag a reformátusok a tiszántúli egyházkerület részei maradtak továbbra is. Az erdélyi rendek számára 1691-ben kiadott Diploma Leopoldinum kedvezőbb helyzetbe hozta az erdélyi reformátusokat, mint a magyarországi egyházigazgatás alatt élő hittestvéreiket (az erdélyi négy bevett vallás addigi jogai megmaradtak). A szilágyi református egyházmegye területén ekkor jelent meg az a törekvés, hogy a tractus az erdélyi református superintendentiához tartozzék. Ráadásul a szilágyi egyházmegye abban a sajátos helyzetben volt, hogy a helyi erdélyi egyházi törvények szerint igazgatták, jelentéseiket az erdélyi református főkonzisztóriumhoz adták be, attól függtek egyházpolitikai ügyekben, a tiszántúli egyházkerülettől pedig egyházfegyelmi ügyekben. Ugyanakkor 1734-ben, amikor egy királyi rendelet megerősítette a tiszántúli református egyházkerület területét, abba természetesen beletartozott a szilágyi egyházmegye is. Ekkoriban a tiszántúli superintendens Zoványi György volt (1728-1758), aki a Közép-Szolnok vármegyében lévő, de a szilágyi tractushoz tartozó Zilahon lakott, s onnan igazgatta a kerületben lévő mind erdélyi, mind magyarországi egyházmegyéket. ${ }^{12}$ Zoványi, aki 1711 óta egyidejüleg krasznai esperes is volt, Szilágynak Erdélyhez tartozását egész egyszerúen gondolta megoldani: 1732-ben Debrecenben felvetődött az egész tiszántúli kerületnek Erdélyhez csatolása. Ez a debreceni egyházmegye jegyzőkönyvében van feljegyezve, ugyanis, minthogy kerületi közgyúlést tiltott volt tartani, az esperesek egy úgynevezett consiliumon tárgyaltak olyan kérdéseket is, amelyek az egész superintendentiát érintették. A Carolina resolutio után vagyunk egy évvel, amikor felmerült a tiszántúli kerület felosztása is, mely szerint az északi partiumi vármegyékben lévő egyházmegyék önálló kerületté szerveződnének. Ekkor olvashatjuk Zoványi javaslatát: „superintendentia maneat in eodem statu, in quo nunc est, nec in duas vel plures dividatur partes, nec etiam exquorundam mente scissio facienda, multo magis nostra Superintendentia Transyylvanicae

11 Kós Károly: Szilágysági levelesládákból. Ethnographia 109(1998).159-167.

12 Magát a forrásokban következetesen a superintendentia Trans- et Cis-Tibiscana superintendensének titulálta. A Cistibiscana, azaz Tiszáninnnen a mai Tiszántúlt jelölte (Erdély felől nézve), a Transtibiscana pedig az ugyanehhez a kerülethez tartozó, de a Tiszán túl lévő egyházigazgatási területet jelentette (Bereg, Ugocsa egy része, Máramaros). 
conjugenda". ${ }^{13}$ Zoványi javaslatát ezen a bizonyos tanácskozáson elvetették, de a püspök leveleiből kitünik, hogy az erdélyi főkonzisztóriumot, annak kérésére, gyakran kereste fel. Emiatt, s a fentiek miatt is, nem egyszer érte az a vád a kerület vagy éppen Harsányi István középszolnoki esperes részéről, hogy egyházmegyéjét Erdélyhez akarja csatolni. 1754-ben ezért a következő végzést hozta a tiszántúli superintendentia: „Relatum est per Reverendum Dominum Stephanum Harsányi Tractus Mediocris Szolnok seniorem, Admodum reverendum Dominum Superintendentem Georgium Zoványi in eo laborare, idque opera praecipuae Illustris Baronis Volfgangi Bánffi, ut majorem Venerabilis Tractus Mediocris Szolnok partem, a reliquo corpore avulsam, Superintendentiae Transylvaniae adjungat. Placuit itaque praesenti congregationi superintendentialis ut primum quidem Venerando Domino Superintendenti notificetur per hanc eandem congregationem, deinde Illustri Baroni per spectabilem Dominum curatorem Michaelem Dobozy; institutum illud prorsus esse impracticabile, nec in effectum deduci inscia Regia majestate posse". ${ }^{14}$ A szilágyi egyházmegye elszakasztására vonatkozó, Zoványi elleni vád nem volt alaptalan. Ô maga írja Wesselényi István erdélyi főgondnoknak 1733 nyarán: „... én e gyümölcstelen és ezer gondú tisztességet meguntam, és mindenkor csak elmémben tartottam Excell[enciád] ama szavait: szakasszam el a Partiumbéli eccl[ézsiá]kat". ${ }^{15}$

Bár ez nem történt meg, egy közel százéves folyamat vette kezdetét, melynek végeztével a korábban debreceni püspökök által irányított Szilágyság majdnem teljes egészében az erdélyi egyházkerület igazgatása alá került. Zoványi György 1758-ban, 101 évesen hunyt el, püspök utódai - Vecsey János (†1763), Tatai Csirke Ferenc (†1765), Szilágyi Sámuel (†1785), Szatmári Paksi István (†1791) - minden szempontból úgy bántak, úgy igazgattak a szilágyi egyházmegyében, mint a többi tractusban. 1767-ben és 1786-ban canonica visitatiót tartottak, válóperes ügyekben hozott egyházmegyei ítéleteket semmisítettek meg, megfenyítettek iskolamestereket, intézkedtek a lelkészektől megtagadott dézsma ügyében, az agentiális pénztárba alamizsnagyüjtést rendeltek el, és 1788-ban felfüggesztették Szilágyban - ahol addig egyedüliként megmaradt - a Zoványi-féle kánonok használatát. ${ }^{16}$

Az első igazi törést a tiszántúli kerület és a szilágyi tractus között egy divortialis házassági (válási) ügy hozta el, amely során 1768-ban Zoványi püspöknek a zsibói lelkészségben szolgáló József nevú fia, ekkor már szilágyi esperes, szembeszállt a kerület akaratával. ${ }^{17}$ Érvénytelenített egy házasságot, ami ellen az egyházkerület tiltakozott, az esperest 1768-1770 között háromszor idézték be a kerület elé, ő azonban a fegyelmi tárgyalásokon egyszer sem jelent meg. Erre maga Wesselényi Ferenc erdélyi főgondnok biztatta, aki a Pérben tartandó első tárgyalást megelőzően 1768. november 9-én Drágban kelt levelében a következőket írta Zoványi Józsefnek: „Tiszteletes Superintendens Uramnak rotunde irja meg T. Esperest Uram, hogy hijában ne is fáradjon Peérbe, mert én parantsoltam, hogy a szilágyiak közül senki oda ne compareáljon, mind azért, hogy Közép-Szolnok és az egész Szilágy Erdéljhez reaplicáltatott, és tam in politicis, quam Ecclesiasticis Erdélji Dicasteriumoktul s Consistoriumtul függ; ... T. Superinten-

13 Tiszántúli Református Egyházkerület Levéltára (a továbbiakban TtREL), I.1. a. 2., 250.

14 TtREL, I.1.a. 3., 304.

15 A Román Nemzeti Levéltárak Kolozs megyei Osztálya, Kolozsvár, A Wesselényi család zsibói levéltára (Fond 250), Fasc. 437.

16 Szabadi István: A szilágyi (krasznai) egyházmegye és az erdélyi egyházkerület kapcsolata a 18. században. Egyháztörténeti Szemle XIV(2013). 4. sz.31-37.

17 TtREL, I.1.b. 121. és 127. Zoványi József szilágyi esperes fegyelmi ügye (1768). 
dens uram ... ö kegyelmének matrimoniális caussákat tractálni nem szabad, melyre nézve ha T. Superintendens Uram mindazokra nem hajtván, Pérbe a magyarországiakkal confluálna és deliberálna is, világosan meg kell irni, minden munkájok és deliberátumokfüstben megyen... Eddig is, hogy a szilágyi Tractusbéliek némely dolgokban a Debreczeni superintendentiához tartottak, és a Debreczeni superintendentiát néminemüképpen agnoscálták, esett onnét, hogy $N$. Tiszteletü Zoványi uram azon Tractusban viselte a superintendentia fejét, és annál fogva subjaceáltak velemennyiben azon superintendentiának, ameddig akartak...". ${ }^{18}$

Közben Lázár János gróf, az új erdélyi főkurátor márciusban levelet írt Debrecenbe a superintendensnek, kérve, hogy ha legközelebb generális synodust tartanak az Erdélyhez tartozó vármegyékben, arról előbb a főkonzisztóriumot értesítsék, kérjék meg engedélyét, s fogadják küldötteiket is, valamint Erdélyben az erdélyi egyházi törvények szerint járjanak el. ${ }^{19}$

Kérték a tiszántúliak azt is Zoványi Józseftől, mint szilágyi esperestől, hogy adja át az egyházmegye iratait a superintendentiának. Az iratok átadását Wesselényi Ferenc maga tagadta meg, s ezért a kerület kérte ez ügyben az erdélyi fookonzisztórium állásfoglalását. Szebenből 1769 augusztusában érkezett meg a levél Lázár János és Teleki László aláírásával, melyben szemére vetették a kerületnek, hogy Tasnádra Debrecenből vittek iskolamestert, pedig az a kolozsvári kollégium beneficiuma volt, felrótták, hogy a szilágyi papoktól taksát szedtek, és hogy a debreceniek részt kívántak némely szilágyi fundusok jövedelméből. Mindezekre hivatkozva úgy döntöttek, hogy a jogbiztosító iratokat tartalmazó levelesláda Zsibón maradjon, „Sibóról meg ne mozdittassék”. ${ }^{20}$

Wesselényi Ferenc 1770-ben meghalt, így ismét szóba került a tractus levelesládájának az ügye. Két listát készítettek a láda tartalmáról, egyiket megkapta a tiszántúli, másikat az erdélyi superintendentia, maguk az iratok pedig ugyanebben az évben, az erdélyi főkonzisztórium akarata szerint, Kolozsvárra kerültek. Ez volt az első eset, amikor az erdélyi fókonzisztórium tettlegesen is beavatkozott az szilágyi tractus ügyeibe. Ettől kezdve, ahogy Pokoly fogalmaz, „az erdélyi fóconsistorium «in ecclatiastico politicis», a tiszántuli egybázkerület pedig «in mere ecclesiasticis» gyakorolta az egyházmegye feletti joghatóságot". ${ }^{21}$ Közben a tiszántúli egyházkerület kezdett megbarátkozni azzal a gondolattal, hogy „az Erdélyhez tartozó eklézsiák a magyarországi eklézsiáktól elszakasztassanak". ${ }^{22}$ Az elszakításra 1818-1821 között került sor, a magyar lakosságát tekintve csaknem színreformátus Szilágyságot egyházkormányzat szempontjából végre Erdélyhez csatolták, de tudjuk, hogy ez az állapot sem tartott, történelmi léptékkel mérve, túl hosszú ideig.

18 TtREL, I.1. b. 121., 3.

19 Uo. I.1.b. 127., 45 .

20 Uo. 51.

21 Рокоцу József: Az erdélyi református egyház története. V. Erdélyi Ev. Ref. Egyházkerület Állandó Igazgatótanácsa, Bp., 1905. 244.

22 ZovánYI Jenő: A tiszántúli református egyházkerület története. Tiszántúli Református Egyházkerület, Debrecen, 1939.90. 


\section{THE AFFILIATION OF SĂLAJ REGION IN THE MIRROR OF THE EARLY MODERN REFORMED ECCLESIASTICAL GOVERNMENT}

Keywords: reformed ecclesiastical government, Transylvania, Tiszántúl Region, Sălaj Region, dual relationship

The reformed dioceses formed in Kraszna and Middle-Szolnok counties became part of the Tiszántúli Reformed Church District in the $16^{\text {th }}$ century (until then their territories belonged to the Bishopric of Transylvania). Because legally it remained part of Transylvania, it was also under the effect of the ecclesiastical laws of Transylvania, and remained there in the $18^{\text {th }}$ centuries, too, in the time of the Habsburg Gubernium. These laws created much favourable conditions for the Protestants in practicing their cult. For this, the whole $18^{\text {th }}$ century was marked by the endeavours of the Protestants from Sălaj to become part of Transylvania not only legally, but in terms of ecclesiastical administration, too, a goal achieved only in the $19^{\text {th }}$ century after a long period of struggles.

\section{APARTENENȚA SĂLAJULUI DIN PERSPECTIVA CONDUCERII ECLEZIASTICE REFORMATE DIN EPOCA PREMODERNĂ}

\section{Cuvinte-cheie: guvernare ecleziastică reformată, Transilvania, regiunea de dincolo de Tisa, regiunea Sălajului, relație duală}

Protopopiatele reformate care s-au format în comitatele Crasna și Solnocul de Mijloc au devenit parte a Eparhiei Reformate de dincolo de Tisa pe parcursul secolului al XVI-lea. Până atunci teritoriul lor a aparținut Episcopiei din Ardeal. Deoarece însă din punct de vedere legal au aparținut în continuare de Transilvania, legile ecleziastice transilvănene au fost valabile și aici, și nu și-au pierdut valabilitatea nici în timpul Guberniului din secolul al XVIII-lea, creând condiții mult mai favorabile protestanților în privința practicării religiei. Din această cauză întreg secolul XVIII a fost marcat de încercările protestanților din Sălaj de a aparține de Transilvania și din punctul de vedere al administrației ecleziastice, deziderat atins abia la începutul secolului al XIX-lea, după o perioadă lungă de încercări. 